\title{
Metabolic Abnormalities in the Pancreatic Islets and Livers of the Diabetic Chinese Hamster
}

\author{
Alberit Y. Chang and Diana I. SohnetDer
}

Diabeies Research, The Upjohn Company, Kalamazoo, Michigan, USA

\begin{abstract}
Summary. The islots of Langerhans isolated from diabetic chinese hamsters had low insulin content, secret. ed less insulin and incorporated leucine $-{ }^{14} \mathrm{C}$ into the insulin fraction at a slower rate than the controls. Livers of these animals were heavier and contained normal levels of glycogen, and of soluble and microsomal proteins. The activities of eight hepatic enzymes were assayed in vitro in three age groups of animals. The diabetic haraster livers showed higher activity in phosphoenolpyruvate carboxykinase, and an elevation in glucose-6-phosphatase was also observed in the three month old diabetic animals. Studies on hepatic fructose-1,6-diphosphatase, glucokinase, hexolkinase, pyruvate kinase, 6-phosphogluconate dehydrogenase and lactate dehydrogenase activities showed no significant change in the non-ketotic, diabetic hamsters, which, however, incorporated pyruvate-2- ${ }^{14} \mathrm{C}$ into blood glucose at a much faster rate. The ketotic hamsters had low activity of glycolytic and pentose phosphate shunt enzymes and high gluconeogenic enzyme activity. There also appoared to be a slight difference in the activity of these enzymes between offsprings of ketotic parents and their controls.
\end{abstract}

Anomaties métaboliques des îlots de Langerhans et du foie chez le hamster chinois diabétique

Résumé. Les îlots de Langerhans isolés, provenant de hamsters chinois diabétiques, présentent un contenu du pancréas diminué en insuline, une sécrétion abaissée d'insuline et une incorporation plus lente de ${ }^{14} \mathrm{C}$-lencine dans la fraction insulinique que les animaux témoins. Le poids $\mathrm{du}$ foie de ces animaux est plus élevé et contient des taux normaux de glycogène ainsi que des protéines solubles et microsomales. On a étudié in vitro les activités de 8 enzymes hépatiques chez trois groupes d'âge de ces animaux. Le foie des hamsters diabétiques montre une activité augmentée de la phosphoénolepyruvate carboxy. kinase ainsi qu'une élévation de la glucose-6-phosphatase chez les animaux diabétiques âgés de 3 mois. L'étude des activités de la fructose-1,6-diphosphatase, do la glucokinase, de l'hexokinase, de la pyruvate-kinase, de la 6-phosphogluconate déhydrogénase et de la lactate déhydrogénase dans le foie n'a pas révélé de modifications significatives chez le hamster diabétique non-cétosique, dont, cependant, l'incorporation du pyruvate-2-24 $\mathrm{C}$ dans le glucose sanguin s'effectue beaucoup plus rapidement. Chez le hamster cétosique, les activités des enzymes de la glycolyse et du cycle des pentoses sont abaissées, alors que celle de la gluconéogénèse est augmentée. Il semble qu'il existe aussi une petite différence dans l'activité de ces enzymes entre les animaux provenant de parents cétosiques et les animaux témoins.

Stoffwechselanomatien in Langerhans'schen Inseln und Leber diabetischer chinesischer Hamster

Zusammenfassung. Aus dem Pankreas diabetischer chinesischer Hamster isolierte Langerhans'sche Inseln enthielten and sezernierten weniger Insulin und inkorporierten weniger Leucin. ${ }^{14} \mathrm{C}$ in eine dem Insulin entsprechende Trennungsfraktion als die Kontrolltiere. Die Lebern dieser diabetischen Tiere waren schwerer als diejenigen von Kontrolltieren, enthielten aber pro Gewichtseinheit normale Mengen von Glykogen, löslichen und mikrosomialen Proteinen. In von chinesischen Hamstern dreier Altersgruppen gewonnenen Leberextrakten wurden 8 für den Glukosestoffwechsel wichtige Enzyme quantitativ bestimmt. Bei diabetischen Tieren war die Aktivität der Phosphoenolpyruvatkarboxykinase und der Glucose6-Phosphatase erhöht. Bei nicht ketotischen diabetischen Hamstern waren die Aktivitäten der Fructose-1,6Diphosphatase, der Glucokinase, der Hexokinase, der Pyruvatkinase, der 6-Phosphogluconat-Dehydrogenase und der Lactat-Dehydrogenase gegenüber der Norm nicht verändert. Trotzdem inkorporierten diese Tiere signifikant mehr Pyruvat-2- ${ }^{14} \mathrm{C}$ in Blutglukose als Normaltiere. Bei ketotisch diabetischen Hamstern waren die Aktivitäten der Enzyme der Glucolyse und des Pentose-Shunts vermindert und diejenigen der Enzyme der gluconeogenetischen Kette erhöht. Qualitativ ähnliche aber quantitativ weniger ausgeprägte Unterschiede wurden zwischen noch nicht diabetischen Nachkommen ketotisch-diabetischer Eltern und deren gleichaltrigen Kontrollen gefunden.

Key-words: Diabetes in animals, chinese hamster, cricetulus griseus, islets of Langerhans, insulin, liver enzymes, liver in diabetes, gluconeogenesis.
The diabetic chinese hamster has aroused particular interest as an experimental animal because of possible similaxity of its disease to human diabetes $[8,11]$. Its metabolic anomalies include hyperglycemia, glucosuria, low plasma and pancreatic insulin content [8], and beta-cell degranulation [2]. Muscle and adipose tissues of the diabetic hamster showed a normal rate of glucose metabolism in vitro and had similar response to insulin as their controls [8]. It was thus suggested that diabetes in the chinese hamsters "may be a result of abnormal insulin secretion by the pancreas and abnormal glucose output by the liver" [8]. This paper summarizes our efforts to relate the metabolic defects observed in the isolated pancreatic islets and certain hepatic enzyme activities to the diabetic syndrome in the animal.

\section{Materials and Methods}

Animals. All animals used were male and selected from the Upjohn colony [8]. The "diabetic" hamsters showed a consistent Tes-Tape value of $4+$ and a negative ketostix test. Those with a positive ketostix test were grouped as the "ketotic" animals. In addition, three offsprings of ketotic parents were studied at an age of fifteen days when sj.gns of glucosuria were absent. All these animals were matched with controls of same age and sex. Animals used in insulin secretion and in 
vivo gluconeogenesis studies were fasted for sixteen hours. Animals used in other studies were allowed food and water ad libitum.

Pancreatic islets. The islets of Langerhans were isolated, and used in insulin secretion and synthesis studies as described previously [3]. Leucine- ${ }^{14 C}(262$ me/mmole) was used as label in studies of insulin synthesis. After four hours of incubation, the islets were extracted with acid alcohol and partially purified with beef insulin as carrier according to Davoren [6]. The precipitates thus obtained were fractionated on a BioGel P30 column $(0.9 \times 60 \mathrm{~cm})$ in $1.0 \mathrm{M}$ acetic acid. The radioactivity associated with bovine insulin peak indicated the amount of leucine: ${ }^{14} \mathrm{C}$ incorporated into hamster insulin.

Liver enzyme assays. Liver supernatant and microsomal fractions were prepared as described before [5]. Glucose-6-phosphatase (Glu6Pase) was assayed in the microsome suspension at $\mathrm{pH} 6.1$ [21]. The activities of the following enzymes were measured in the super. natant fraction according to methods described in the references: phosphoenolpyruvate carboxykinase (PEPCK) [26], fructose-1,6-diphosphatase (Fru 1,6DPase) [28], glucokinase (GluKase) [24], hexokinase (Hex Kase) [24], pyruvate kinase (PyrKase) [25], 6-phosphogluconate dehydrogenase (6PG d'ase) [10], lactate dehydrogenase (LDH) [27], and pyruvate carboxylase (Pyr CB) [5]. In some cases, the glucose phosphorylating activity was measured in $0.1 \mathrm{M}$ glucose without further correction and was abbreviated as GluHexKase.

In vivo gluconeogenesis. Sodium pyruvate-2. ${ }^{14} \mathrm{C}$ ( $5 \mu \mathrm{C}$ in $0.2 \mathrm{ml}$ saline, $3.44 \mu \mathrm{C} / \mu$ mole) was injected intraperitoneally and about $0.15 \mathrm{ml}$ blood was collected through orbital sinus at $0,5,10,15$ and $20 \mathrm{~min}$. An aliquot of $0.1 \mathrm{ml}$ blood was transferred to $0.5 \mathrm{ml}$ icecold water, and $0.2 \mathrm{ml}$ each of $0.3 \mathrm{~N} \mathrm{Ba}(\mathrm{OH})_{2}$ and $5 \%$ $\mathrm{ZnSO}_{4}$ was added in succession. The contents were mixed thoroughly on a Vortex mixer between each addition. After centrifugation, deproteinized blood was collected. Two aliquots of $0.01 \mathrm{ml}$ whole blood were counted to estimate the amount of radioactivity absorbed into circulation.

Aliquots of $0.1 \mathrm{ml}$ deproteinized blood were used to measure blood glucose with glucose oxidase [22]. In determination of blood ${ }^{14} \mathrm{C}$-glucose, two aliquots of $0.2 \mathrm{ml}$ deproteinized blood were used. One (blank) was incubated with $0.5 \mathrm{ml} \mathrm{H} \mathrm{H}_{2} 0$ at $37^{\circ} \mathrm{C}$. The second aliquot (sample) was incubated with $0.5 \mathrm{ml}$ "PGO" enzyme solution (Sigma) which was made by dissolving one capsule of enzymes in $50 \mathrm{ml} \mathrm{H}_{2} \mathrm{O}$. After 60 minutes, the incubated mixtures were passed through columns packed in disposable pipettes, consisting of $2 \mathrm{~cm}$ beds

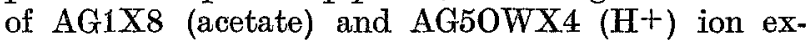
change resins, separated by $2 \mathrm{~mm}$ acid-washed sea sand. The tubes and columns were washed with three additions of $0.5 \mathrm{ml} \mathrm{H} \mathrm{H}_{2} \mathrm{O}$ and the combined eluants were counted. The difference in radioactivity present in the eluants from "blank" and "sample" represented the amount of ${ }^{14} \mathrm{C}$-glucose in $0.2 \mathrm{ml}$ aliquots of deproteinized blood.

After the last bleeding, the animals were decapitated and liver homogenates were prepared and enzymes were assayed as described [5].

Miscellaneous. Spectrophotometric assays were carried out in a Beckmann DB-Spectrophotometer. Radioactivity was measured in Bray solution [1] in a Packard Tricarb Scintillation Spectrometer and corrected for quenching by channel-ratio method [12]. Protein determination was performed according to Lowry et al. [17] and blood glucose was measured on an autoanalyzer [14]. Plasma insulin was determined by the double antibody immunoassay [20] and liver glycogen was precipitated from $30 \% \mathrm{KOH}$ extract [15] and measured with the phenolsulfuric acid method [7].

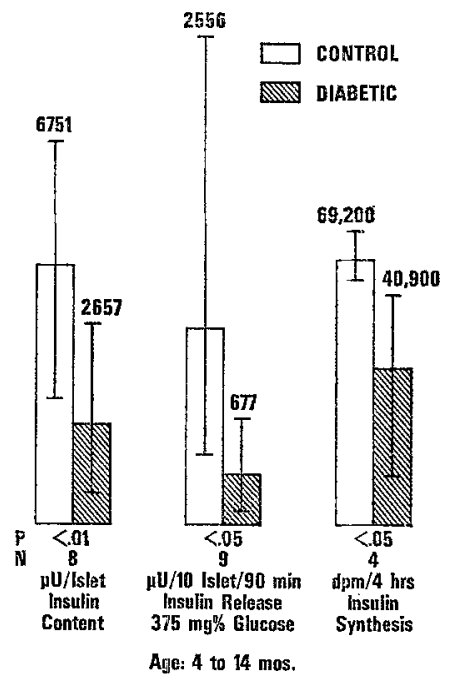

Fig. 1. Insulin content, secretion and synthesis in isolated. islets of Langerhans. Numbers indicate the mean of results obtained from studies on $\mathrm{N}$ animals.

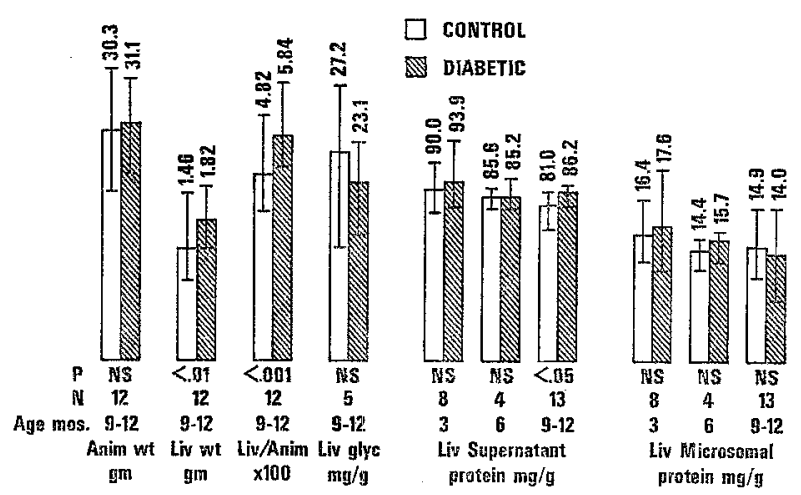

Fig. 2. Various properties of livers of the chinese hamsters.

Substrates, coenzymes and enzymes used in assays were purchased from Boehringer-Mannheim, New York, or Sigma, St. Louis. $\mathrm{NaH}^{14} \mathrm{CO}_{3}$, leucine ${ }^{14} \mathrm{C}$ and sodium-2. ${ }^{14} \mathrm{C}$-pyruvate were obtained from Now Fingland Nuclear, Boston. Ion exchange resins were supplied by BioRad Laboratories, Richmond, California. 


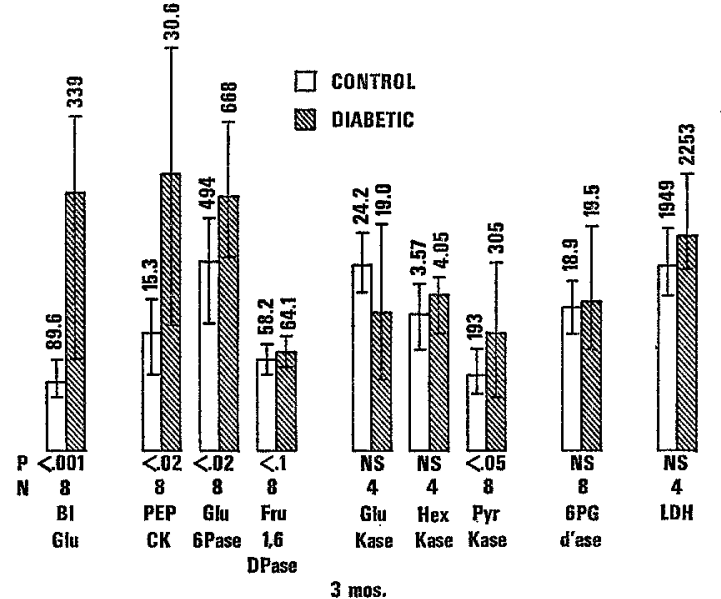

Fig. $3 a$

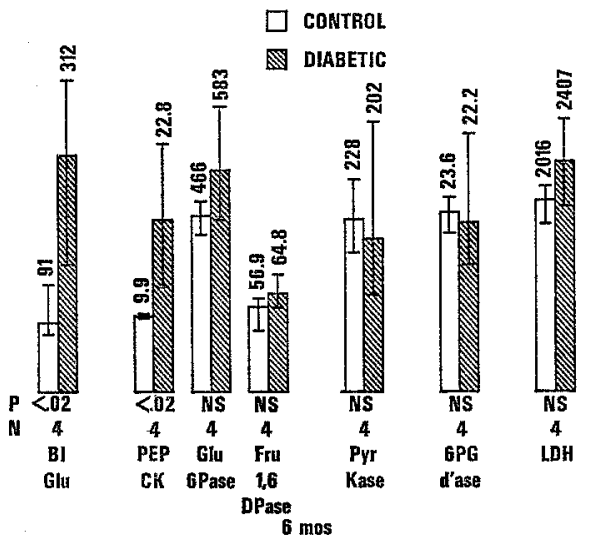

Fig. $3 \mathrm{~b}$
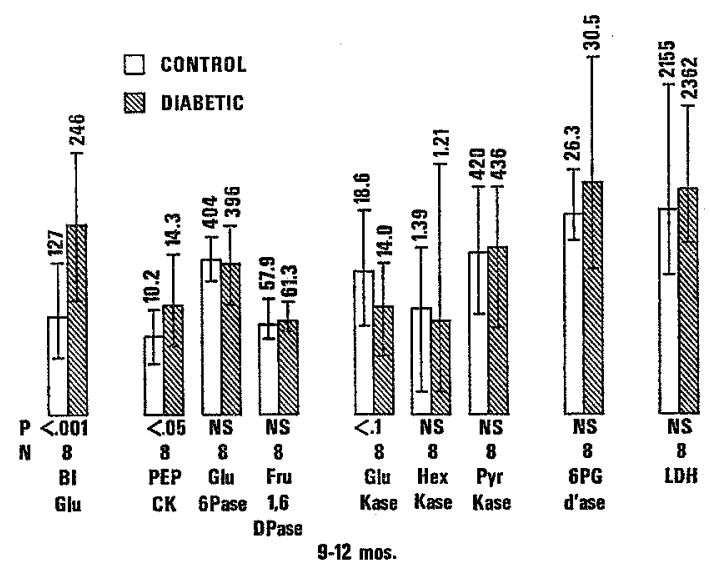

Fig. $3 \mathrm{c}$

Fig. 3. Activities of the hepatic enzymes of chinese hamsters. Numbers indicate the mean of specific activity of individual enzyme obtained from studies on $\mathrm{N}$ animals. Specific activity was defined as mumole substrate turnover per minute per $\mathrm{mg}$ protein in the enzyme fraction. $\mathrm{Ab}$ breviation for enzymes was described in Materials and Methods. Glu6Pase was assayed in the microsomal fractions at $37^{\circ} \mathrm{C}$. Other enzymes were measured in the supernatants at $37^{\circ} \mathrm{C}$ (PEPCK, Fru 1, 6DPase) or $25^{\circ} \mathrm{C}$ (GluKase, HexKase, PyrKase, 6PGdase and LDH).

\section{Results}

Islets of Langerhans. The islets of Langerhans isolated from the diabetic chinese hamsters contained less insulin than the nondiabetics (Fig. 1). In vitro studies on glucose-dependent insulin secretion revealed that the diabetic hamster secreted less insulin than the nondiabetics when assayed under the same condition. Likewise, the amount of leucine- ${ }^{14} \mathrm{C}$ incorporated into insulin fraction was less in the diabetic hamster islets.

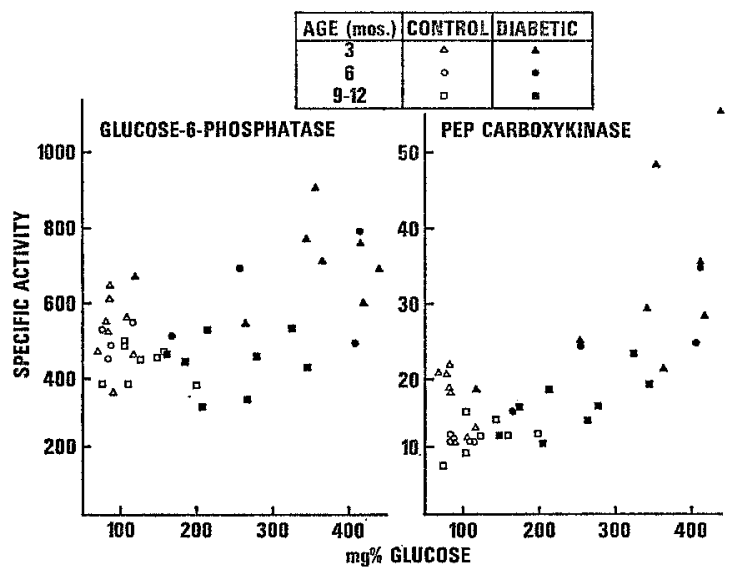

Fig. 4. Activities of Glu6Pase and PEPCK vs. Blood Glucose

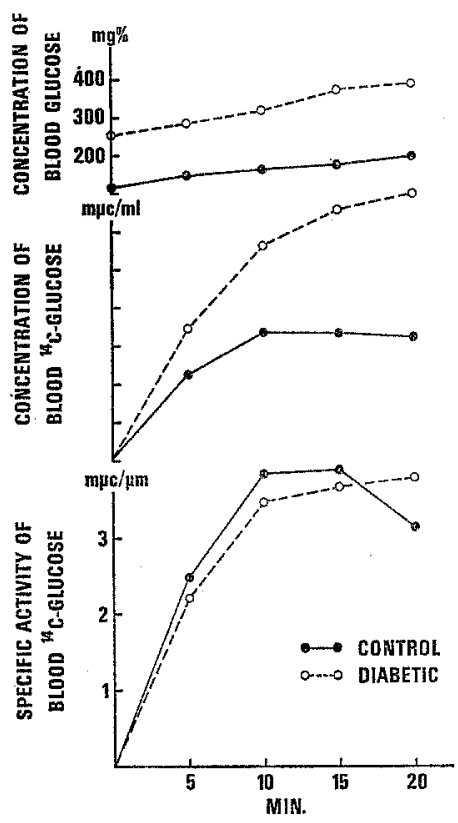

Fig. 5. Concentration and specific activity of blood ${ }^{14} \mathrm{C}-$ glucose in the chinese hamsters during in vivo gluconeogenesis studies. Each point represents the mean of seven determinations

Livers. The diabetic hamsters had similar weights as their controls but their livers appeared to be slightly larger (Fig. 2). The enlargement of the liver in the diabetics was more evident when expressed as per- 
cent body weight. However, there was no significant difference in liver glycogen, and soluble and microsomal proteins between these two groups of animals, except that a slight increase in the supernatant proteins was observed in the 9 to 12 month group of diabetic hamsters.

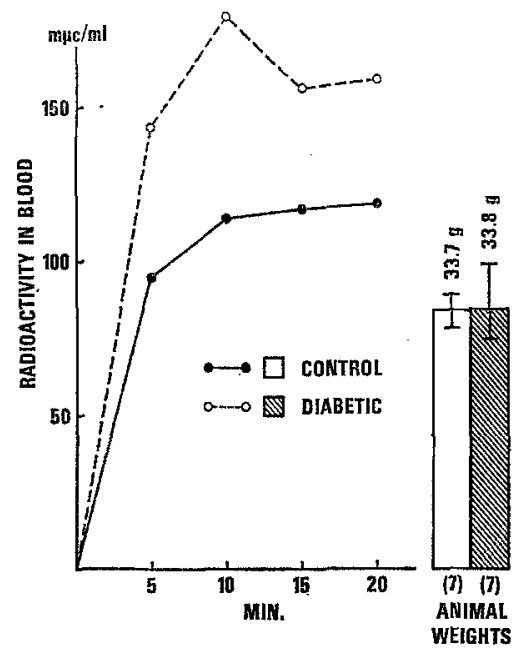

Fig. 6. Rate of absorption after I.P. injection in the chinese hamsters. Five $\mu \mathrm{C}$ of pyruvate-2 ${ }^{14} \mathrm{C}$ was administered into hamsters weighing 29.4 to 39.9. Each point represents the mean of seven studies

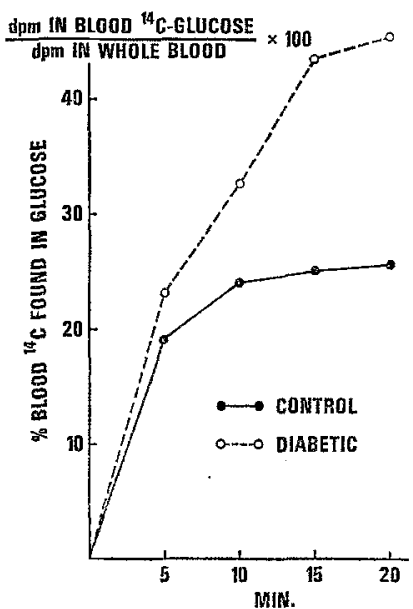

Fig. 7. Rate of ${ }^{14} \mathrm{C}$-glucose formation from sodium pyruvate-2- ${ }^{14} \mathrm{C}$. Each point represents the mean of seven studies

Liver enzymes. The level of eight hepatic enzymes was studied in three different age groups of animals, and the onsets of glucosuria in these animals were first observed at the age of one to two months. Blood glucose concentration was measured as an index of degree of severity in hyperglycemia. As shown in Fig. 3, the 9 to 12 month old diabetics had a lower blood glucose level than the 3 month old diabetics $(p \sim 0.05)$. Among the three gluconeogenic enzymos assayed, phosphoenolpyruvate carboxykinase was present in a consistently elevated level in the diabetics, but the deviation lessened as the animals grew older. A significant increase in glucose-6-phosphatase and pyruvate kinase was also observed in the 3 month old diabetic hamsters. There appeared to be no differenoe in the activity of fructose-1,6-diphosphatase, glucokinase, hexokinase, 6-phosphogluconate dehydrogenase and lactate dehydrogenase between the diabetios and controls.

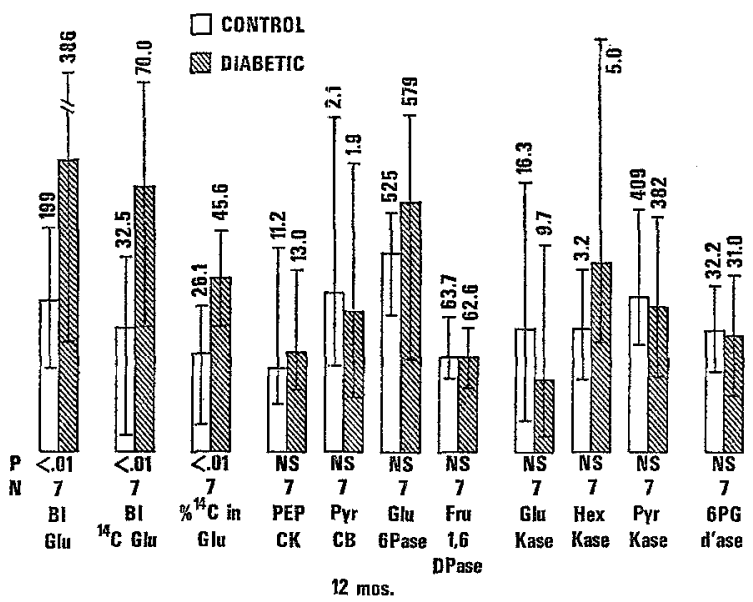

Fig. 8. Activities of hepatic enzymes in hamsters used in in vivo gluconeogenesis studies. The concentrations of blood glucose and blood ${ }^{14} \mathrm{C}$-glucose, and $\%$ blood ${ }^{14} \mathrm{C}$ in glucose were measured in blood collected just before decapitation of hamsters. Also see legends in Fig. 3

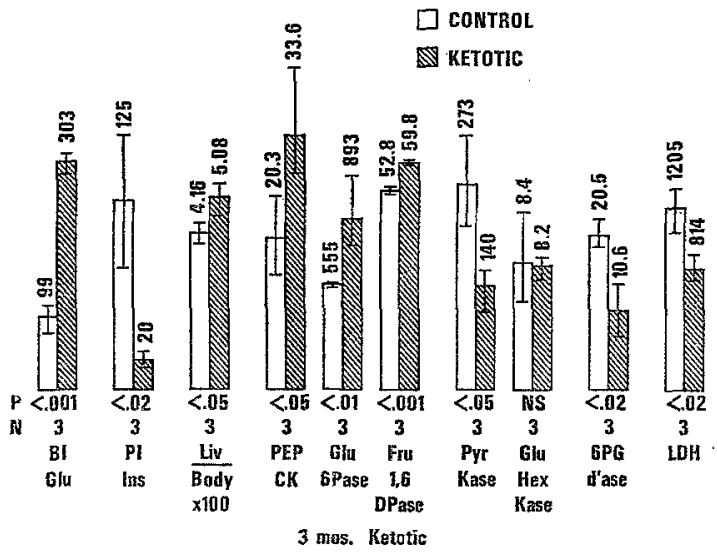

Fig. 9. Activities of hepatic enzymes in ketotic hamsters. See legends in Fig. 3

Liver enzymes vs. blood glucose. When the activity of hepatic enzyme was plotted against blood glucose concentration, a direct correspondence between the level of phosphoenolpyruvate carboxykinase and the degree of severity of hyperglycemia was observed (Fig. 4). A more pronounced elevation of the activities of hepatic phosphoenolpyruvate carboxykinase and glucose-6-phosphatase in the young diabetics was also evident.

In vivo gluconeogenesis vs. liver enzymes. The rate of incorporation of sodium pyruvate-2. ${ }^{14} \mathrm{C}$ into blood ghu- 
cose was studied in seven pairs of fasted hamsters. The animals were under stress and a rise in blood glucose was observed (Fig. 5a). The diabetic hamster showed a consistently higher blood sugar concentration and a faster rate of blood ${ }^{14} \mathrm{C}$-glucose formation (Fig. $5 \mathrm{~b}$ ). Absorption of radioactive substrate into circulation after intraperitoneal injection also appeared to be facilitated in the diabetics (Fig. 6). Taking this into consideration, the rate of gluconeogenesis from circulating radioactive precursors was calculated (Fig. 7) and significantly faster rate was observed in the diabetic animals.

At the end of twenty minutes, the animals were killed and the levels of eight hepatic enzymes were studied and no significant difference between the two groups was observed (Fig. 8).

Liver enzymes in ketotic hamsters. Studies on liver enzymes of young ketotic hamsters are summarized in Fig. 9. The three gluconeogenic enzymes were present in a significantly increased amount, whereas the levels of pyruvate kinase, 6-phosphogluconate dehydrogenase, and lactate dehydrogenase were depressed in the ketotic animals. The glucose-phosphorylating activity measured at $0.1 \mathrm{M}$ glucose concentration was similar in both groups of animals.

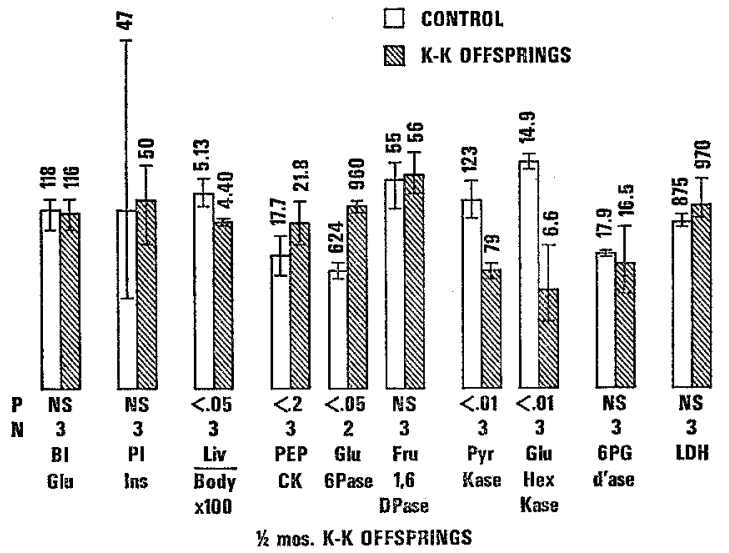

Fig. 10. Activities of hepatic enzymes in "potential" diabetic hamsters. See legends in Fig. 3

Liver enzymes in "potential" diabetics. The incidence of diabetes in the offsprings from ketotic matings is $100 \%$ [9]. At the age of 15 days, these animals showed normal blood sugar and plasma insulin levels, and less than normal liver weight (Fig. 10). However, a significant elevation of glucose-6-phosphatase and a decrease in pyruvate kinase and glucose-phosphorylating activity was detected.

\section{Discussion}

The objectives of our studies on the chinese hamsters were twofold. The first objective was to study the metabolic abnormalities associated with pancreatic insulin content in the diabetic hamsters [8]. The second objective was to find out the biochemical defects which immediately precede the manifestation of hyperglycemia.

Our studies on the isolated pancreatic islets confirmed the notion that abnormal metabolism in the islets plays an important role in causing diabetes mellitus in the chinese hamsters $[8,2,19,18]$. The diabetic hamster islets do not synthesize insulin at a normal rate. The decreased rate of insulin synthesis results in a subnormal insulin content in the islets which in turn causes a reduced rate of insulin secretion [3].

Hyperglycemia arises from underutilization and/or overproduction of glucose. Since it is generally held that the rate of a metabolic pathway is reflected by the level of enzymes regulating that pathway, studies on the levels of gluconeogenic and glucose-catabolizing enzymes in tissues where glucose is actively synthesized and metabolized will reveal the immediate cause of hyperglycemia. In alloxan- [29] and streptozotocindiabetic rats [5], diabetic [4] and obese hyperglycemic mice [23], abnormal hepatic enzyme levels have been reported. Our studies on the ketotic, diabetic hamster livers indicate an exorbitant quantity of gluconeogenic enzymes and depressed level of glucose-catabolizing enzymes which may result from plasma insulin deficiency [29]. However, the finding that offsprings of ketotic parents also have subnormal level of hepatic glycolytic enzymes and elevated gluconeogenic enzymes prior to the onset of hyperglycemia and hypoinsulinemia, suggests an early involvement of liver in causing diabetes in these ketotic animals.

In the non-ketotic diabetic hamsters, hepatic enzyme levels vary considerably and only the young ones show significantly elevated activity in some gluconeogenic enzymes. Since onset of ketosis in chinese hamsters can be as late as ten months [9], the non-ketotic animals studied at the age of three and six months may include some "potential" ketotic diabetics. Therefore, it appears that the non-ketotic, diabetic hamsters do not have abnormal quantities of hepatic gluconeogenic and glucose-catabolizing enzymes. However, these animals have an accelerated rate of $i n$ vivo gluconeogenesis from pyruvate and its metabolites. This finding suggests that hyperglycemia in the non-ketotic diabetic hamsters may arise from an abnormal rate of gluconeogenesis in sites other than liver, such as kidney cortex [16]. Alternatively, the rate of hepatic gluconeogenesis may be further regulated by limiting factors, e.g. substrate concentration [13], other than the levels of gluconeogenic enzymes. Studies on the rate of pyruvate conversion into glucose in kidney and liver slices are now in progress in our laboratory.

The diabetic hamsters have a higher rate of $a b=$ sorption after intraperitoneal injection. The abnormal rate of absorption in the diabetic animals may result from two causes: defective membrane or hypertonicity in blood. The high osmolarity due to elevated blood glucose concentration may facilitate the transport of injected isotonic solution. 
In conclusion, our studies reveal that the diabetic hamsters have a defective machinery in insulin synthesis. Hyperglycemia can be, at least in part, attributed to an accelerated rate of gluconeogenesis. The ketotic, diabetic hamsters also have aberrant levels of hepatic gluconeogenic and glucose-catabolizing enzymes. However, the non-ketotic, diabetic hamsters have normal levels of hepatic enzymes, and how significant a role that liver plays in causing hyperglycemia in these animals is still uncertain.

Acknowledgements: The authors express thoir appreeiation to Dr. G.C. Gerritsen and Mr. L. Needham for providing the animals.

\section{References}

1. Bray, G.A.: A simple efficient liquid scintillation for counting aqueous solutions in a liquid scintillation counter. Analyt. Biochem. 1, 279-285 (1960).

2. Carpenter, A.M., Gerritsen, G.C., Dulin, W.E., Lazarow, A.: Islet and beta-cell volumes in diabetic chinese hamsters and their nondiabetic siblings. Diabetologia 3, 92-96 (1967).

3. Chang, A.Y.: Insulin synthesis and secretion by isolated islets of spontaneously diabetic chinese hamsters. The Second Symposium in the Structure and Metabolism of the Pancreatic Islets. Pergamon Press. In press (1969).

4. - Schneider, D.I.: Abnormalities in hepatic enzyme activities during development of diabetes in the $d b$ mouse. Diabetologia, 6, 274-278 (1970).

5. - - Aberrations in hepatic enzyme activities in streptozotocin-diabetic rats. Submitted to Diabetes.

6. Davoren, P.R.: The isolation of insulin from a single cat pancreas. Biochim. biophys. Acta 63, 150-153 (1962).

7. Dubois, M., Gilles, K.A., Hamilton, J.K., Rebers, P.A., Smith, F.: Colorimetric method for determination of sugars and related substances. Analyt. Chem. 28, 350-356 (1956).

8. Gerritsen, G.C., Dulin, W.E.: Characterization of diabetes in the chinese hamster. Diabetologia $\mathbf{3}$, $74-84(1967)$.

9. - Needham, L.B., Schmidt, F.L., Dulin, W.E.: Studies on the prediction and development of diabetes in offspring of diabetic chinese hamsters. Diabetologia, 6, 158-162 (1970).

10. Glock, G.E., McLean, P.: Further studies on the properties and assay of glucose-6-phosphate dehydrogenase and 6-phosphogluconate dehydrogenase of rat liver. Biochem. J. 55, 400-408 (1953).

11. Gundersen, K., Yerganian, G.E., Lin, B.J., Gagnon, H., Bell, F., McRae, W., Onsberg, T.: Diabetes in the chinese hamster; some clinical and metabolic aspects. Diabetologia 3, 85-91 (1967).

12. Herberg, R.J.: Channels ratio method of quench correction in liquid scintillation counting. Packard Technical Bulletin No. 15 (1965).
13. Herrera, J.G., Kamm, D., Ruderman, N., Cahill, G. F., Jr.: Non-hormonal factors in the control of gluconeogenesis. Adv. Enzyme Reg. 4, 225-235 (1965).

14. Hoffman, W.S.: A rapid photoelectrie method for the determination of glucose in blood and urine. J. biol. Chern. 120, 51-55 (1937).

15. Huijing, F., Nutall, F., Villar-Palasi, C., Larner, J.: UDP-Glucose- $\alpha$-1,4-glucan $\alpha$-4-glucosyl-transferase in heart. Regulation of the activity of the transferase in vivo and in vitro in rat. A dissociation in the action of insulin on transport and on transferase conversion. Biochim. biophys. Acta 177, 204-212 (1969).

16. Krebs, H. A.: Renal gluconeogenesis. Adv. Enzyme Reg. 1, 385-400 (1963).

17. Lowry, O.H., Rosebrough, N.J., Farr, A.L., Randall, R.J.: Protein measurement with the Folin-phenol reagent. J. biol. Chem. 193, 265-275 (1951).

18. Luse, S. A., Caramia, F'., Gerritsen, G. C., Dulin, W.E. : Spontaneous diabetes mellitus in the chinese hamster: An electron microscopic study of the islets of Langerhans. Diabetologia 3, 97-108 (1967).

19. Malaisse, W., Malaisse-Lagae, F., Gerritsen, G.C., Dulin, W.E.: Insulin secretion in vitro by the pancreas of the chinese hamster. Diabetologia 3, 109-114 (1967).

20. Morgan, C.R., Lazarow, A.: Immunoassay of insulin ; two antibody systems. Diabetes 12, $115-126$ (1963).

21. Nordlie, R.C., Snole, R.E.: Regulation of liver microsomal inorganic pyrophosphate, glucose phosphotransferase, glucose-6-phosphatase and inorganic pyrophosphatase. Biochim. biophys. Acta 148, 222232 (1967).

22. Raabo, E., Terkildsen, T.C.: On the enzymatic determination of blood glucose. Scand. J, clin. Lab. Invest. 12, 402-407 (1960).

23. Seidman, I., Horland, A.A., Teebor, G.W.: Hepatic glycolytic and gluconeogenic enzymes of the obesehyperglycemic mouse. Biochim. biophys. Acta 146, $600-603(1967)$.

24. Sharma, C., Manjeshwar, R., Weinhouse, S.: Adenosine Triphosphate phosphotransferase of rat liver. J. biol. Chem. 238, 3840-3845 (1963).

25. Shonk, C.E., Boxer, G. E.: Enzyme patterns in human tissues. I. Methods for the determination of glycolytic enzymes. Cancer Res. 24, 709-721 (1964).

26. Wagle, S.R., Ashmore, J.: Studies on carbon dioxide fixation in normal and alloxan-diabetic animals. Biochim. biophys. Acta 74, 564-565 (1963).

27. Weber, G.: Effect of six day starvation on rat liver lactic dehydrogenase activity. J. Nutr. 71, 156--158 $(1960)$.

28. - Cantero, A.: Fructose-1,6-diphosphatase and lactic dehydrogenase activity in hepatoma and in control human and animal tissue. Cancer Res. 19, 763-768 (1959).

29. - Singhal, R.L., Scrivastava, S.K.: Insulin: suppressor of biosynthesis of hepatic gluconeogenic enzymes. Proc. nat. Acad. Sci. 53, 96-104 (1965).

Dr. A.Y. Chang

Diabetes Research

The Upjohn Company

Kalamazoo, Michigan, USA 